\title{
Eating attitudes and behaviours in a sample of female university students: does studying nutrition and dietetics make a difference?
}

Tetyana Rocks, Fiona Pelly, Lisa Martin, Gary Slater

From 2014 ANZAED Conference: Driven Bodies Driven Brains

Fremantle, Australia. 22-23 August 2014

Eating attitudes and behaviours of female students enrolled in the discipline of Nutrition and Dietetics (ND) in Australia has not been previously explored. Therefore, the aim of this study was to examine these characteristics in undergraduate ND students in comparison to a group of female students enrolled in Occupational Therapy (OT). A cross-sectional data was initiated in AugustOctober 2013 as part of longitudinal research investigating dietary and exercise behaviours and practices, plus body composition of this cohort. Previously validated questionnaires, including the Eating Attitudes Test, the Three-Factor Eating Questionnaire, the Rosenberg SelfEsteem Scale, and the Body Shape Questionnaire were administered to students to assess eating behaviours, selfesteem and body dissatisfaction respectively. Overall, 119 females students (75 ND and 44 OT) participated in this part of the study. Preliminary results suggest no significant differences in eating behaviours, self-esteem and body dissatisfaction between student populations. However, almost two thirds of the participants have indicated mild to marked concern with body shape despite the mean reported Body Mass Index of $23.1 \mathrm{~kg} / \mathrm{m} 2$. The associations between eating attitudes and demographic, physiological and psychological characteristics of this sample will be presented. Implications for future studies in this population will be discussed.

Published: 24 November 2014

*Correspondence: tetyana.rocks@research.usc.edu.au

University of the Sunshine Coast, Sunshine Coast, Australia
doi:10.1186/2050-2974-2-S1-P12

Cite this article as: Rocks et al:: Eating attitudes and behaviours in a sample of female university students: does studying nutrition and dietetics make a difference? Journal of Eating Disorders 2014 2(Suppl 1): P12.
Submit your next manuscript to BioMed Central and take full advantage of:

- Convenient online submission

- Thorough peer review

- No space constraints or color figure charges

- Immediate publication on acceptance

- Inclusion in PubMed, CAS, Scopus and Google Scholar

- Research which is freely available for redistribution
() Biomed Central 